\title{
Manometric and mass spectrometric analysis of fluids in geological materials
}

\author{
Jean-Louis Zimmermann ${ }^{1}$, Albert Jambon ${ }^{2}$ and Gilbert Guyetand ${ }^{1}$ \\ Centre de Recherches Pétrographiques et Géochimiques, \\ CNRS, 15 rue Notre Dame des Pauvres, BP 20, \\ 54501 Vandoeuvre lès nancy Cedex ${ }^{1}$ and \\ Université Pierre et Marie Curie, Laboratoire de Magmatologie \\ et Géochimie Inorganique et Expérimentale, \\ Tour 26, 4 Place Jussieu, 75252 Paris Cedex 05, France ${ }^{2}$
}

(Received December 23, 1987; Accepted March 18, 1988)

\begin{abstract}
A procedure of volatile analysis in rocks which permits quantitative estimation of all the volatile species of any geological interest is presented and illustrated by several examples. Gas extraction is performed either by vacuum crushing or heating. A separation line using cold traps, oxidation $\left(\mathrm{CO}\right.$ to $\left.\mathrm{CO}_{2}\right)$ and reduction $\left(\mathrm{H}_{2} \mathrm{O}\right.$ to $\left.\mathrm{H}_{2}\right)$ furnaces permits to separate several fractions. At the end of each separation phase the pressure in the line is measured with a capacitance manometer before analysis of the gas mixture with a mass spectrometer. Calibration is done periodically using standard gases stored in gauged bottles. The detection limits are 0.5 to $1 . \times 10^{-7} \mathrm{~mol} \mathrm{H}_{2} \mathrm{O}, 0.3 \times 10^{-7} \mathrm{~mol} \mathrm{CO}_{2}$ and about $0.2 \times 10^{-7} \mathrm{~mol}$ for $\mathrm{H}_{2}, \mathrm{~N}_{2}, \mathrm{CO}, \mathrm{CH}_{4}$ and $\mathrm{Ar}$. Further species like organic compounds, $\mathrm{SO}_{2}$ and $\mathrm{H}_{2} \mathrm{~S}$ are detected but not determined. In the case of $\mathrm{H}_{2} \mathrm{O}$ and $\mathrm{CO}_{2}$ the reproducibility is better than $4 \%$. The conjunction of vacuum crushing, stepwise heating and size fraction analysis permits to separate components like: dissolved, adsorbed and vesicle trapped. In particular, effects of adsorption have been evaluated: it is a serious problem for species like $\mathrm{CO}_{2}$ and $\mathrm{H}_{2} \mathrm{O}$ with finely crushed material. $\mathrm{H}_{2}$ and $\mathrm{CO}$ detected after thermal extraction when organic compounds are present in the sample reflect organic decomposition rather than any thermodynamic equilibrium attained upon rock formation.
\end{abstract}

\section{INTRODUCTION}

Geological materials contain variable amounts of fluids (mostly $\mathrm{H}_{2} \mathrm{O}$ and $\mathrm{CO}_{2}$ ) which have been trapped during their formation. These fluids are potential tracers of the original environments and provide information about the solidification conditions (composition, pressure, temperature) in magmatic, volcanic or hydrothermal processes. In addition, radiogenic gases like helium and argon produced in the rocks from the disintegration of $\mathrm{U}, \mathrm{Th}$ and $\mathrm{K}$ allow these rocks to be dated.

Gases are generally trapped as inclusions in minerals or as bubbles in glasses (quenched melts); they can also be trapped in cracks, cleavages and defects of crystals, as well as dissolved in the solid, inserting or substituting in the crystal lattice. Gas can also be adsorbed at grain boundaries: eventhough these are usually not counted as initial gases they may obscure the analytical results.

Previous works (Wahler, 1958; Goguel, 1963; Chaigneau, 1967; Roedder, 1972; Zimmermann, 1972; Piperov and Penchev, 1973; Harris, 1981) showed that fluids in rocks are essentially water and carbon dioxide in addition to small quantities of hydrogen, carbon monoxide, nitrogen, methane and organic compounds, hydrogen sulphide, sulphur dioxide and rare gases. These fluids can be analysed by two kinds of analytical processes: punctual techniques like 
microthermometry (Roedder, 1972; Weisbrod et al., 1976; Cheilletz et al., 1984) and Raman spectrometry (Cheiletz et al., 1984) global techniques such as gas chromatography (Chaigneau, 1967; Behar, 1978; Andrawes and Gibson, 1979) and mass spectrometry (Zimmermann, 1972; Cheilletz et al., 1984; Muenow, 1973).

The first ones are non destructive but apply only to major fluids in transparent minerals.

The second ones are destructive but enable the bulk analysis of fluids released by crushing or heating, of all kind of materials in particular basalts, magmatic glass, volcanic rocks, meteorites and lunar rocks (Andrawes and Gibson, 1979).

In our procedure, gases may be extracted either by crushing or heating under vacuum and subsequently separated before analysis by a coupled method of manometry (Goguel, 1963; Piperov and Penchev, 1973; Harris, 1981) and mass spectrometry.

\section{Preparation of Samples}

Before extraction of their gases, the samples must be prepared carefully in order to reduce, as far as possible, any contaminants.

After a coarse crushing, between $0.4 \mathrm{~mm}$ and $4 \mathrm{~mm}$, samples are hand picked under a binocular microscope. Pieces from 0.4 to $2 \mathrm{~mm}$ are stored for vacuum heating. Smaller pieces are usually discarded as they collect large amounts of adsorbed atmospheric contaminants. Pieces larger than $2 \mathrm{~mm}$ present too long degassing kinetics resulting in poor yields of extraction within reasonable times, they are therefore reserved for crushing under vacuum.

In the lavas of the Ardoukôba (Zimmermann et al., 1981), plagioclase phenocrysts have been separated from the mesostasis (glass +olivine and pyroxenes microcrysts) under binocular microscope. The fractions were subsequently cleaned with distilled water in an ultrasonic bath (Jambon and Zimmermann, 1987).

Minerals like quartz (Cheilletz et al., 1984) are cleaned either in $0.4 \mathrm{~N}$ hydrofluoric acid for 20 minutes or for the same length of time, in a mixture of $100 \mathrm{~cm}^{3}$ concentrated nitric acid and of a few $\mathrm{cm}^{3}$ of hydrogen peroxide.

The role of acid is to widen the cracks, to dissolve carbonate impurities, and in conjunction with hydrogen peroxide, to eliminate traces of organic matter which may contaminate the samples.

After the acid wash come several rinses in distilled water and a $110^{\circ} \mathrm{C}$ heating overnight. With ferrobasalts however, nitric acid and hydrogen peroxide produce an oxidation of the iron which brings about a loss of gases. In this case, only one cleaning in an ultrasonic bath is used. Samples subject to crushing, weigh between 1 and $5 \mathrm{~g}$; for heating, charges between 50 and $300 \mathrm{mg}$ have been used.

Oceanic basalt glasses are cleaned with $\mathrm{HCl}$ and $\mathrm{HF}, \mathrm{H}_{2} \mathrm{O}$ mixtures and rinsed to remove external surfaces possibly contaminated by seawater as well as crushing dust.

\section{EXTRACTION OF GASES}

In our experiments two procedures of gas extraction have been used: vacuum crushing (Price and al., 1977) in a stainless steel crushing finger or heating in a quartz furnace. Both are linked to a gas separation line whose function is to chemically split the extracted gaseous mixture into several fractions before introduction into the ionization cell of the mass spectrometer.

\section{Crushing under vacuum}

The container is $20 \mathrm{~cm}$ long and $1 \mathrm{~cm}$ diameter stainless steel finger which is first cleaned with trichloro-ethylene for $15 \mathrm{~h}$ and subsequently with a mixture of nitric acid, hydrofluoric acid and water $\left(45 \% \mathrm{HNO}_{3}, 5 \% \mathrm{HF}\right.$, $50 \% \mathrm{H}_{2} \mathrm{O}$ ) for $20 \mathrm{~min}$ to pickle the internal surface. After rinsing with distilled water, the finger is kept at $110^{\circ} \mathrm{C}$ in an oven until needed.

Before sample introduction, the tube is connected to the vacuum line at $10^{-3}-10^{-4}$ Torr, and heated with an oxyacetylene torch to about $600^{\circ} \mathrm{C}$ in order to release gases trapped in the steel. After cooling the finger is opened and the several chunks (about one to several grams) are introduced. It is gently heated to $120^{\circ} \mathrm{C}$ under pumping between $10^{-6}$ and $10^{-7}$ Torr, to extract 
any adsorbed atmospheric volatiles. A stopcock permits to disconnect the finger without breaking vacuum (Fig. 1).

It is then placed under the ram of a hydraulic press and the tip containing the sample is crushed under fifteen tons force. The finger is then immediately connected back to the line. Air traped between the stopcock and the entrance metal tap of the line is pumped out, whilst the finger is reheated at $120^{\circ} \mathrm{C}$ to avoid adsorption of gases onto its walls or on the new surfaces of the powdered sample. This crushing procedure is the same as the one used to extract fluids from rocks for isotope measurements of hydrogen and oxygen (Rye and O'Neil, 1968; Sheppard, 1971).

\section{Heating under vacuum}

The extraction furnace is a removable resistance furnace regulated by a temperature controller (JUMO) connected to a Pt-Pt $\mathrm{Pt}_{90} \mathrm{Rh}_{10}$ thermocouple and operating in the range up to $1200^{\circ} \mathrm{C}$. A horizontal silica tube, $20 \mathrm{~cm}$ long, permits sliding a silica boat which contains the sample. Before analysis, degassing at $1200^{\circ} \mathrm{C}$ of the furnace and the boat for at least twelve hours is carried out until the blank has decreased to an acceptable level.

Samples weighing between 50 and $300 \mathrm{mg}$ are placed in the silica boat. An overnight baking at $140^{\circ} \mathrm{C}$ eliminates partially adsorbed gases. There are routinely three types of experiments feasible with such a device:

1) Heating with only one or two temperature steps, at $500^{\circ} \mathrm{C}$ and $1200^{\circ} \mathrm{C}$, during a minimum time of $3.5 \mathrm{~h}$, to release all the gases.

2) Incremental heating from $200^{\circ} \mathrm{C}$ to $1200^{\circ} \mathrm{C}$

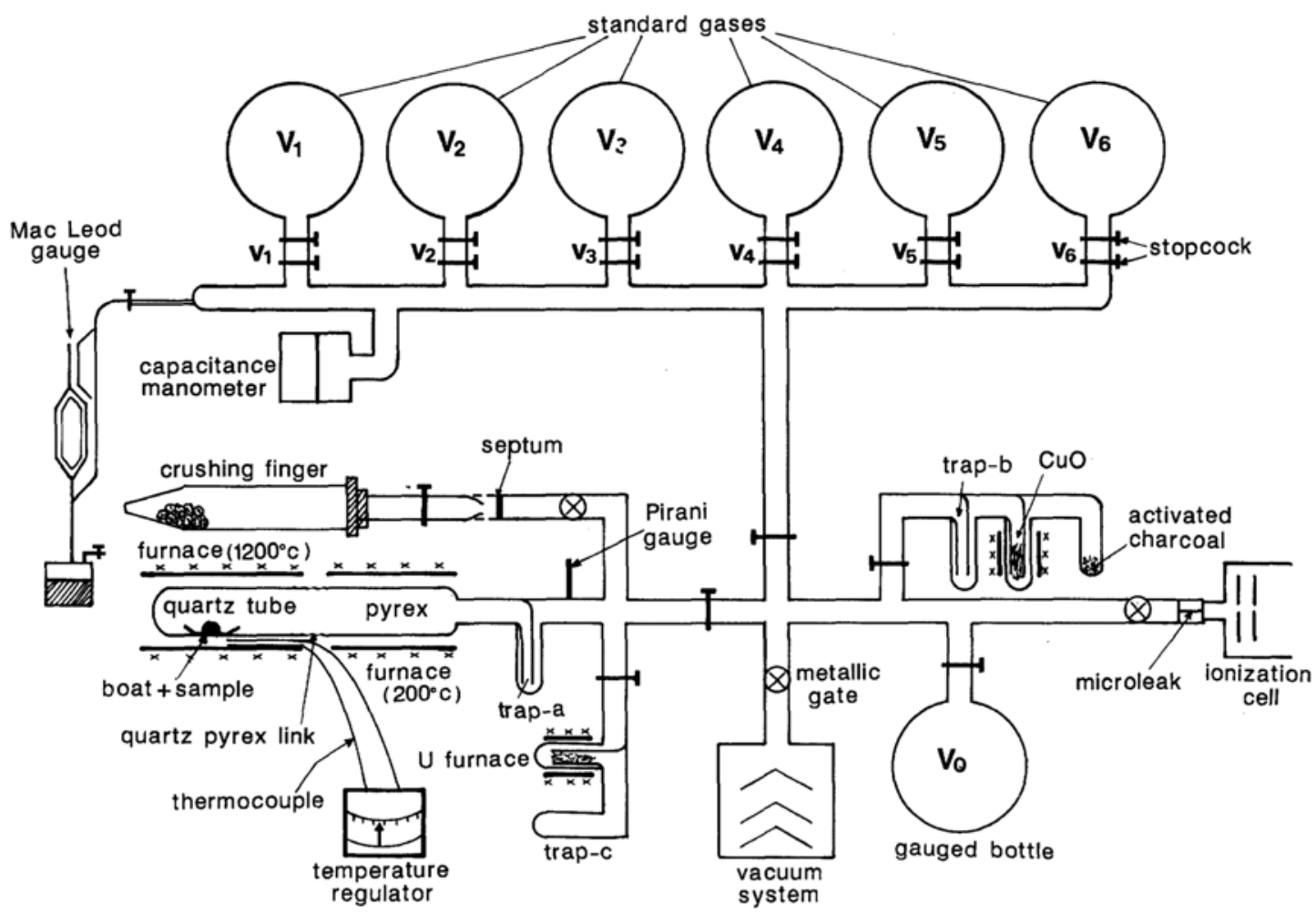

Fig. 1. Schematic diagram of the extraction and separation line. Extraction by heating in a quartz furnace or by crushing in a stainless steel tube. Separation in cold traps before and after oxidation or reduction of gases. Volumetric and manometric measurements by means of a Mac Leod gauge and of a capacitance manometer. Introduction of gases in the mass spectrometer through a microleak. Calibration with standard gases stored in gauged bottles. 
with successive steps of $100^{\circ} \mathrm{C}$. Temperature is kept constant until gas pressure levels off to a constant value. A Pirani gauge (LKB) placed out of the quartz furnace permits to evaluate this pressure; stability is obtained after heating for about $2.5-3 \mathrm{~h}$. This procedure permits the analysis of the fluid released at each temperature step, and to determine a liberation pattern for every sample. The diffusion characteristics can also be calculated (activation energies, diffusion constants) (Zimmermann, 1981; Zimmermann et al., 1987).

3) Continuous and linear heating, from $140^{\circ} \mathrm{C}$ to $1200^{\circ} \mathrm{C}$ with three different rates $\left(5^{\circ} \mathrm{C} / \mathrm{min}\right.$, $6.66^{\circ} \mathrm{C} / \mathrm{min}$ and $10^{\circ} \mathrm{C} / \mathrm{min}$ ) is also possible.

This permits to observe continuous release of each gas. The corresponding curves are similar to differential thermogravimetric curves. They also give the kinetic characteristics of the release of gases, essentially of water and carbon dioxide, possibly of hydrogen and methane, using Horowitz and Metzger method (1963).

\section{SeParation OF GaSES}

When a gas is analysed by mass spectrometry, ionization breaks the molecule up, so that it is characterized by a series of peaks which form its own mass spectrum (Mc Lafferty, 1980). Analysis of a gaseous mixture leads to mass interferences which must be avoided in order to identify and measure accurately each gas. Moreover, abundant quantities of gas result in a poor ionization efficiency. To overcome these difficulties, a preliminary separation permits selective introduction to the mass spectrometer source.

A pyrex separation line is connected to the extraction systems on one side and to the mass spectrometer through a metallic gate and a microleak. On the other it is composed of a succession of cold traps and furnaces. In addition a calibration system (Fig. 1) containing pure gases permits periodical calibration.

The vacuum system consists of a two stage primary pump (Edwards E2M8) and a mercury diffusion pump (Edwards Speedivac) equiped with a liquid nitrogen trap; it provides a $10^{-6}$
$10^{-7}$ Torr vacuum. A Baratron capacitance manometer (MKS, 220B), working in the range from $10^{-6}$ to 10 Torrs and connected to a digital voltmeter (BBC.M2110) permits an accurate measurement of pressure during gas separation. The line is constantly baked at $80^{\circ} \mathrm{C}$ with a heating ribbon in order to avoid adsorption. As the whole line is kept at constant temperature, this permits an accurate determination of the amount of gas in the line. The volume of this line with its quartz extraction tube is close to 400 $\mathrm{cm}^{3}$, determined to within $1.5 \%$.

In the case of gas rich samples, a $1100-\mathrm{cm}^{3}$ bottle allows the gas pressure to be lowered; this bottle is kept at $80^{\circ} \mathrm{C}$ with a resistance heater.

Upon completion of an extraction step, gases are separated according to their boiling temperature in the cold trap (a) (Table 1) as will be de-

Table 1. Schematic representation of the separation of released gases from geological samples.

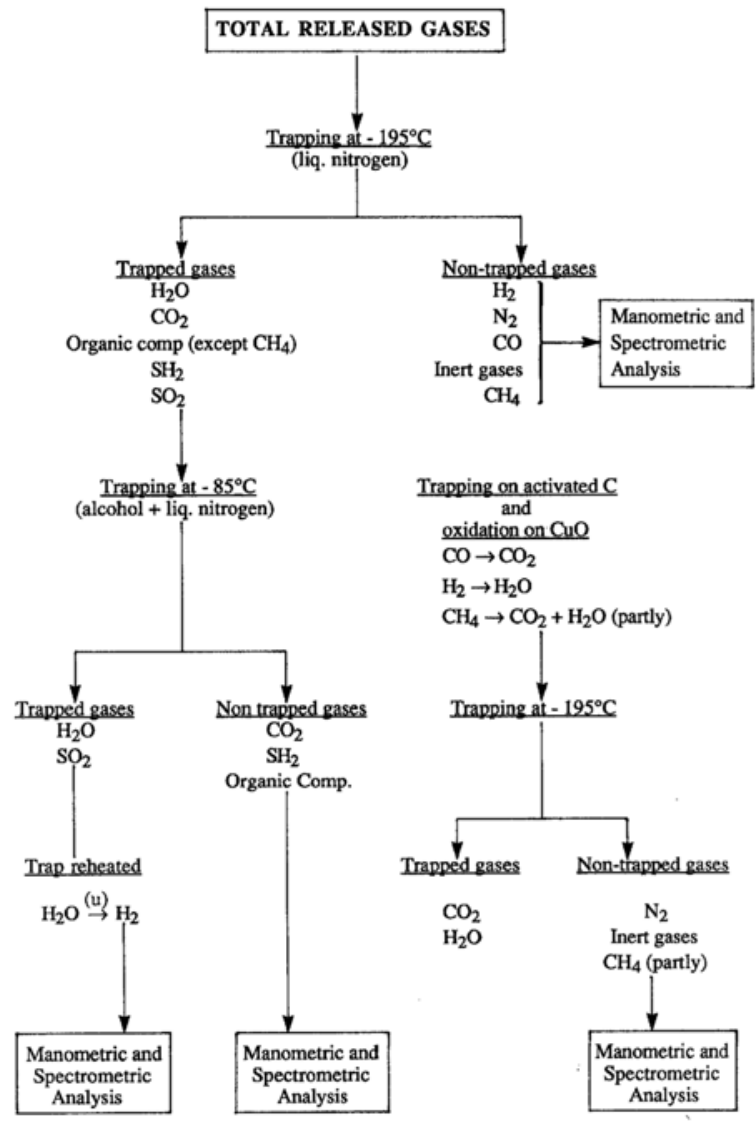


scribed now.

During extraction keeping a trap at liquid nitrogen temperature $\left(-195^{\circ} \mathrm{C}\right)$ permits to collect the condensable gases. This permits to keep a very low pressure in the extraction furnace, increasing the extraction efficiency and reducing any adsorption or reaction with the line walls. Hydrogen, nitrogen, carbon monoxide, methane and rare gases which are not condensed at this temperature may be analysed in the mass spectrometer without further separation. Nitrogen and carbon monoxide which have the same principal mass (28 molecular mass) can be distinguished by their secondary mass, 14 and 12 , respectively, in the spectrum. However, as the presence of methane may affect this measurement, a part of the line is reserved for oxidation. After completion of an overall mass spectrum, these non condensed gases are trapped on activated charcoal at $-195^{\circ} \mathrm{C}$, then reheated to $300^{\circ} \mathrm{C}$ and forced to pass over hot cupric oxide at $300^{\circ} \mathrm{C}$ where $\mathrm{H}_{2}$ and $\mathrm{CO}$ are oxidized to $\mathrm{H}_{2} \mathrm{O}$ and $\mathrm{CO}_{2}$ and trapped at $-195^{\circ} \mathrm{C}$ in another trap (b). Nitrogen alone remains, and can be analysed accurately. After completion of the analysis of non condensable gases, the line is evacuated in order to permit analysis of condensed volatiles.

The first cold trap (a), which was kept at $-195^{\circ} \mathrm{C}$, is warmed up to $-85^{\circ} \mathrm{C}$ (with an alcohol+liquid nitrogen mixture). Water and sulphur dioxide (if present in the sample) stay in the trap whereas carbon dioxide, hydrocarbons $(C>2)$ and hydrogen sulphide are released and analysed.

After pumping out this second fraction, the cold trap (a) at $-85^{\circ} \mathrm{C}$ is heated to $200^{\circ} \mathrm{C}$ with a resistance furnace. Direct measurement of water yields poor reproducibility because of its adsorbtion onto the walls of both the line and the mass spectrometer source. To avoid this problem, water is reduced to hydrogen by being repeatedly passed over hot uranium at $750^{\circ} \mathrm{C}$ (Craig, 1961) between cold trap a and c (Fig. 1). The hydrogen so obtained is analysed in the mass spectrometer.

At the end of each separation step, pressure is measured with the capacitance manometer before introduction to the mass spectrometer.
This permits to know the amount of gas in the fraction to be analysed and a cross check with mass spectrometric measurements.

\section{Mass Spectrometric Analysis}

Gases are analysed by means of a magnetic sector $180^{\circ}$, THN 205 modified, mass spectrometer.

Gases flow from the separation line to the ionization cell through a microleak whose diameter is less than 0.1 millimeter. Upstream pressure seldom exceeds a few torr (2-3 Torr maximum); so the flow through the microleak is molecular. Particles are ionized by electronic bombardement and accelerated with a high voltage linearly variable from 0 to $1500 \mathrm{~V}$. They follow a circular path in a constant magnetic field of 3950 gauss.

The apparatus has two ion collectors and therefore can investigate simultaneously two mass ranges with the same high voltage scanning. The radius of ionic paths are $2 \mathrm{~cm}$ (mass from 2 to 10 ) and $5 \mathrm{~cm}$ (mass higher than 10) respectively. A switch connects successively each collector with the amplifier. The sensitivity limit is about $10^{-13} \mathrm{~A}$. Before each analysis a residual spectrum is recorded, which is used for blank correction. For every constituent of a mixture, the decrease of pressure, with time, in the ionization source is inversely proportional to the square root of its molecular mass; this is scarcely perceptible as scanning over the whole spectrum is completed within a few minutes. The ratio of ionic current to the quantity of gas consumed per unit time, is a spectrometer constant for each gas. It depends on the entrance microleak, the ionization cell characteristics and the power of the pumping system. Since the pressure in front of the microleak is low, and since the volume of the separation line is comparatively large, the mixture composition remains constant and each component behaves as if it was alone: the ionic current corresponding to a gas is in this case independent of the presence of other gases. Moreover, selective introduction of gases, as described above, limits the number of mixture components, and therefore the mass interferences 
and the total pressure as the two major components $\mathrm{CO}_{2}$ and $\mathrm{H}_{2}$ from $\mathrm{H}_{2} \mathrm{O}$ are analysed separately.

\section{Calibrations}

Quantitative estimation is made by peak height comparison to standards run periodically.

Pure standards of argon, nitrogen, carbon dioxide, carbon monoxide, hydrogen and methane are stored in gauged bottles $\left(3400 \mathrm{~cm}^{3}\right.$ within $0.1 \%$ ); their initial pressures are measured by means of a Mac Leod gauge. They are introduced into the mass spectrometer, as small volumes $\left(4 \mathrm{~cm}^{3}\right.$, measured with an accuracy of $1.5 \%$ ) (Fig. 1), before or after each analysis. These gases can also be mixed in known proportions.

The calibration analyses not only calibrate the mass spectrometer but also the capacitance manometer. Double calibration permits to avoid any calibration error, owing to the small sensitivity variation of the mass spectrometer (Fig. 2).

Besides, a small quantity of pure argon can be mixed with the gases released from the sample during analysis to highlight any variations in ionization, because wear of the filament causes a decrease of ionization efficiency with time.

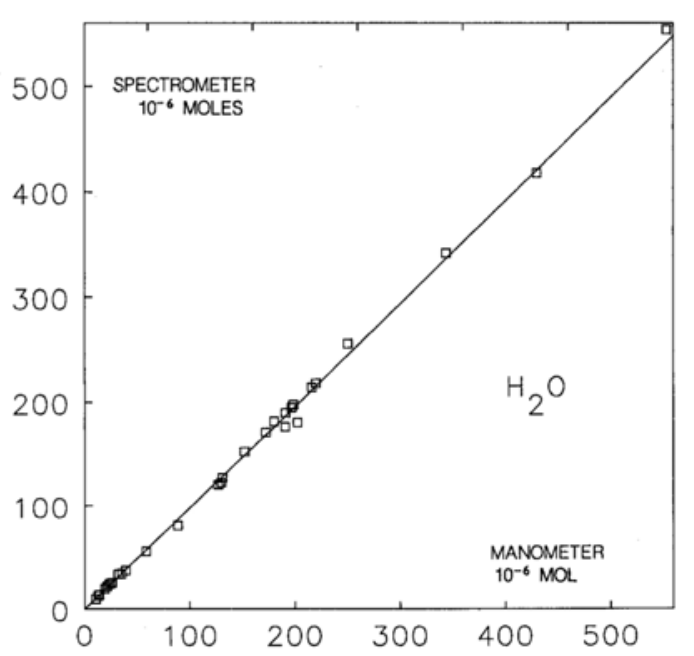

Taking a standard gas as an example; let $V=$ the volume of its bottle, and $v=$ the small known volume whose content is analysed periodically. $N_{0}=$ initial number of atoms in the bottle, which is obtained by measuring the pressure with a Mac Leod gauge. The initial number of atoms in $v$ will be: $n_{0}=N_{0} v / V$.

At the first calibration the number of atoms will be:

$$
n_{1}=N_{0} v / V(V / V+v)=n_{0}(V / V+v)^{1}
$$

At the $n$th calibration:

$$
n_{n}=N_{0} v / V(V / V+v)^{n}=n_{0}(V / V+v)^{n}
$$

With argon as the standard, the actual value are:

$V=3352 \pm 2 \mathrm{~cm}^{3}, \quad v=3.84 \pm 0.06 \mathrm{~cm}^{3}$

$V /(V+v)$

$=0.99885, \quad N_{0}=0.002078$ gram-atom

and $n_{0}=2.38 \times 10^{-6}$ gram-atom

A more accurate measurement of argon is undertaken in potassic materials (Zimmermann et al., 1985) using another mass spectrometer, with ${ }^{38} \mathrm{Ar}$ as a spike.

In the case of water, its reduction over hot

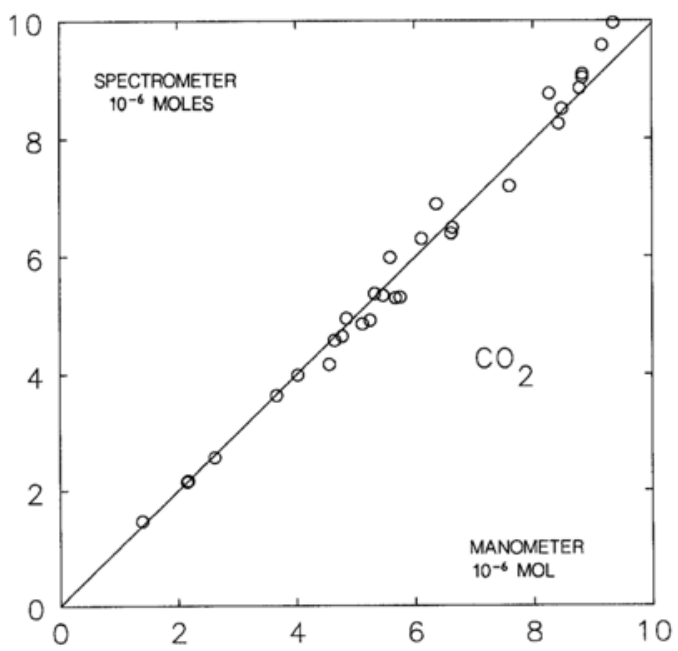

Fig. 2. The best fit lines relating the manometric and mass spectrometric measurements of $\mathrm{H}_{2} \mathrm{O}$ and $\mathrm{CO}_{2} . \mathrm{H}_{2} \mathrm{O}$ reduced to $\mathrm{H}_{2}$-slope: $0.978 \pm 0.007$; intercept: $0.031 \pm 0.201$; correlation coefficient: 0.991 . CO${ }_{2}$-slope: $0.994 \pm 0.01$; intercept: $0.011 \pm 0.038$; correlation coefficient: 0.9939 . 
uranium eliminates adsorption. Known quantities of water, between 0.2 and $1 \mu \mathrm{l}$, can be introduced into the separation line by means of a Hamilton microsyringe and so reduced. Further calibration can be done using standard glasses doped with small amounts of water.

\section{Results and Discussion}

\section{Major volatiles $\mathrm{H}_{2} \mathrm{O}$ and $\mathrm{CO}_{2}$}

These are the two most abundant volatile species in rocks. The detection limit of the method is $0.5-1 . \times 10^{-7} \mathrm{~mol}$ for water, $0.3-$
$0.5 \times 10^{-7} \mathrm{~mol}$ for $\mathrm{CO}_{2}$. This represents the amount of $\mathrm{H}_{2} \mathrm{O}$ and $\mathrm{CO}_{2}$ contained in about 1.5 $\mathrm{mg}$ and $3 \mathrm{mg}$ of the basalts analysed (Table 2) and comparable amounts for quartz samples of Table 3. In the case of water the reproducibility has been drastically improved over previous procedures of analyzing $\mathrm{H}_{2} \mathrm{O}$ as such, instead of converting it to $\mathrm{H}_{2}$ before analysis. This is illustrated quantitatively by the results obtained for basalt glass (CH98-DR11), $1200^{\circ} \mathrm{C}$ step (after a first step at $500^{\circ} \mathrm{C}$ ). The results for seven size fractions ranging from $160-200 \mu \mathrm{m}$ to $2500-3150 \mu \mathrm{m}$

Table 2. Molar composition of fluid phase extractd by heating of lavas from different origins (steps at $500^{\circ} \mathrm{C}$ and $1200^{\circ} \mathrm{C}$ )

\begin{tabular}{|c|c|c|c|c|c|c|c|c|c|c|c|}
\hline $\mathrm{N}^{\circ}$ & $\begin{array}{l}\text { Origin and } \\
\text { Material }\end{array}$ & $\begin{array}{l}\text { Total content } \\
10^{-5} \mathrm{~mol} / \mathrm{g}\end{array}$ & $\begin{array}{c}\mathrm{H}_{2} \mathrm{O} \\
\%\end{array}$ & $\begin{array}{c}\mathrm{CO}_{2} \\
\%\end{array}$ & $\begin{array}{c}\mathrm{CO} \\
\%\end{array}$ & $\begin{array}{l}\mathrm{N}_{2} \\
\%\end{array}$ & $\begin{array}{l}\mathrm{H}_{2} \\
\%\end{array}$ & $\begin{array}{c}\mathrm{CH}_{4} \\
\%\end{array}$ & $\begin{array}{c}\text { Organic } \\
\text { compounds }\end{array}$ & $\mathrm{SO}_{2}$ & $\mathrm{SH}_{2}$ \\
\hline AR 79-6 & $\begin{array}{l}\text { Arenal } \\
\text { andesite }\end{array}$ & 6.85 & 67.3 & 20.2 & 10.9 & 1.5 & 0.06 & 0.01 & $* *$ & $\varepsilon$ & - \\
\hline AR $80-8$ & $\begin{array}{l}\text { Arenal } \\
\text { andesite }\end{array}$ & 6.36 & 68.1 & 19.4 & 10.7 & 1.6 & 0.09 & 0.01 & $*$ & $*$ & - \\
\hline AR 81-1 & $\begin{array}{l}\text { Arenal } \\
\text { andesite }\end{array}$ & 7.97 & 63.5 & 24.0 & 10.8 & 1.6 & 0.06 & 0.01 & $*$ & $*$ & - \\
\hline AR 81-2 & $\begin{array}{l}\text { Arenal } \\
\text { andesite }\end{array}$ & 7.77 & 65.7 & 22.8 & 9.8 & 1.5 & 0.08 & 0.02 & $*$ & $* *$ & - \\
\hline CH98.DR11 & $\begin{array}{l}\text { North Atlantic } \\
\text { basaltic glass }\end{array}$ & 16.84 & 92.6 & 5.8 & 1.3 & 0.1 & 0.06 & 0.1 & $*$ & $\varepsilon$ & $\varepsilon$ \\
\hline CYP.78.03.05 & $\begin{array}{l}\text { Pacific Ridge } \\
\text { basaltic glass }\end{array}$ & 21.40 & 81.0 & 12.1 & 6.1 & 0.1 & 0.4 & 0.3 & $\varepsilon$ & - & $\varepsilon$ \\
\hline CYP.78.10.19 & $\begin{array}{l}\text { Pacific Ridge } \\
\text { basaltic glass }\end{array}$ & 22.48 & 64.2 & 17.0 & 13.1 & 1.9 & 2.9 & 0.6 & $*$ & - & $\varepsilon$ \\
\hline AH $83 \mathrm{KL} 3$ & $\begin{array}{l}\text { Kilauea, Hawaï } \\
\text { subaerial lava }\end{array}$ & 9.7 & 66.4 & 22.3 & 7 & 1.3 & 2.4 & 0.3 & $*$ & - & - \\
\hline RE 451 & $\begin{array}{l}\text { La Fournaise } \\
\text { Réunion Island } \\
\text { subaerial lava }\end{array}$ & 9.45 & 83.5 & 15.5 & 0.7 & 0.03 & 0.2 & 0.06 & $\varepsilon$ & - & - \\
\hline P0P1.DR2a & $\begin{array}{l}\text { Okinawa, Japan } \\
\text { basaltic glass }\end{array}$ & 61.3 & 97.1 & 2.5 & 0.07 & 0.17 & 0.15 & 0.03 & $\varepsilon$ & - & $\varepsilon$ \\
\hline
\end{tabular}

*; present in small quantities, ${ }^{* *}$; present in larger quantities, $\varepsilon$; traces

Table 3. Molar composition of fluid phase extracted by heating at $500^{\circ} \mathrm{C}$ or by crushing of two quartz samples from hydrothermal veins CG 495. Gold vein from Bourneix (Hte Vienne, France). AM 653. tungsten vein from Djebel Aouam (Morocco).

\begin{tabular}{|c|c|c|c|c|c|c|c|c|c|}
\hline $\mathrm{N}^{\circ}$ & Origin & Extraction & $\begin{array}{c}\text { Total content } \\
10^{-5} \mathrm{~mol} / \mathrm{g}\end{array}$ & $\begin{array}{c}\mathrm{H}_{2} \mathrm{O} \\
\%\end{array}$ & $\begin{array}{c}\mathrm{CO}_{2} \\
\%\end{array}$ & $\begin{array}{l}\mathrm{N}_{2} \\
\%\end{array}$ & $\begin{array}{l}\mathrm{H}_{2} \\
\%\end{array}$ & $\begin{array}{c}\mathrm{CH}_{4} \\
\%\end{array}$ & $\begin{array}{c}\text { Organic } \\
\text { compounds }\end{array}$ \\
\hline CG 495 & $\begin{array}{l}\text { Quartz } \\
\text { Bourneix }\end{array}$ & $\begin{array}{l}\text { Heating } \\
500^{\circ} \mathrm{C}\end{array}$ & 6.6 & 92.5 & 4.5 & 1.2 & 1.4 & 0.4 & - \\
\hline CG 495 & Bourneix & Crushing & 1.7 & 94.8 & 2.7 & 2.3 & - & 0.2 & - \\
\hline AM 653 & $\begin{array}{l}\text { Quartz } \\
\text { Aouam }\end{array}$ & $\begin{array}{l}\text { Heating } \\
500^{\circ} \mathrm{C}\end{array}$ & 26 & 83.5 & 15.5 & 0.03 & 0.03 & 0.9 & $*$ \\
\hline
\end{tabular}

\footnotetext{
*; present in small quantities
} 
yield with the procedure of conversion to $\mathrm{H}_{2}$ a standard deviation of $3.5 \%$ on the water content. Similar measurements made previously on the same set of size fractions, but without converting $\mathrm{H}_{2} \mathrm{O}$ to $\mathrm{H}_{2}$ yielded a standard deviation of $12.1 \%$.

A similar improvement is observed for $\mathrm{CO}_{2}$ as the standard deviation is decreased from $29 \%$ to $3.3 \%$ when analysed separately from water (as a consequence of $\mathrm{H}_{2} \mathrm{O}$ conversion to $\mathrm{H}_{2}$ ). Alone these numbers do not strictly correspond to mass spectrometric reproducibility as part of the dispersion might also result from sample heterogeneity. However, comparison with manometric measurement (Fig. 2) permits to resolve this point. As the scatter in the correlation is comparable with mass spectrometric reproducibility among the previous set of measurements, there is no evidence whatsoever that the sample is heterogeneous. Because of the manometric measurement, the results represent an accurate absolute abundance in the sample for all species analysed. Combination of crushing, size fraction analysis, stepwise heating permit to separate several components: adsorbed, trapped in vesicle, dissolved in silicate matrix (Jambon and Zimmermann, 1987). A similar interpetation is not feasible with micromanometric measurements.

On the other hand variations from one sample to the other in excess of the deviations reported above (one $\sigma_{\text {water }}=3.5 \%$, one $\sigma_{\mathrm{CO}_{2}}=3.3 \%$ ) have to be interpreted in the light of realistic processes (partial melting, fractionation, contamination) whose discussion is beyond the scope of this paper.

In the case of $\mathrm{CO}_{2}$ (Javoy et al., 1978) a small part can be the result of occluded carbonates (Reitsema, 1979) which are detected neither optically nor by X-ray diffraction $(<2 \%)$. With the possible exception of this uncertainty, the greatest part of $\mathrm{CO}_{2}$ which is released by heating at $1200^{\circ} \mathrm{C}$ and crushing comes from the vesicles in the samples. Below $500^{\circ} \mathrm{C}$ (incremental heating), $\mathrm{CO}_{2}$ is extracted and separated at the same time as hydrocarbons; therefore if propane is present it can interfere with $\mathrm{CO}_{2}$ at mass 44 . In the materials studied, there are negligible quantities of propane. Otherwise the fragment peaks should be detected.

\section{Trace volatiles}

Trace gases may be divided into two subclasses: organic compounds and inorganic ones, like $\mathrm{H}_{2}, \mathrm{CO}, \mathrm{N}_{2}, \mathrm{SO}_{2}, \mathrm{H}_{2} \mathrm{O}$, etc.

Organic compounds Mass spectrometric analysis of organic compounds has expanded drastically over the last decade and reached a high level of sophistication. Because of the difficult problems of cracking, mass decomposition and overlap with the other components the interpretation of the results is always difficult when abundant and numerous organic compounds are present. The present technique permits to detect the presence of organic compounds by a number of dissociation masses (12, $13,14,15,26,28,30,36,39,41,42,43)$. Because of thermal dissociation these are released at low temperature $\left(<500^{\circ} \mathrm{C}\right)$ by crushing or stepwise heating. Trivial contamination being eliminated by $\left(\mathrm{HNO}_{3}+\mathrm{H}_{2} \mathrm{O}_{2}\right)$ leaching after careful selection under the microscope, the presence of light organic compounds represents trapped organic matter, most of the time in fluids inclusions or microcracks. For instance hydrothermal quartz reveals almost constantly the presence of $\mathrm{CH}_{4}$ but heavier compounds are not always present.

The method is sensitive enough to reveal organic compounds in basalt glasses. In the particular case of basalt glass (CH98-DR11) further study has shown that these light species obtained at $500^{\circ} \mathrm{C}$ are the result of cracking of heavy carbonaceous components (Jambon and Zimmermann, 1984).

Although $\mathrm{CH}_{4}$ is sometimes found in plutonic rocks (Gold, 1982) and in volcanic materials (Zimmermann et al., 1987) as traces, it is most abundant in hydrothermal minerals. It is generally an indication of the presence of heavier organic compounds (Kranz, 1970) whose few cracking peaks are found in the mass spectra of gases released from the cold trap at $-85^{\circ} \mathrm{C}$. This organic matter can be trapped by geological 
materials during their travel through the lithosphere and the biosphere or during their crystallisation. A part can also be the result of pollution somewhere between sampling and analysis.

Inorganic compounds Though hydrogen and carbon monoxide are found in exhalated volcanic gases (Chaigneau and Fuster, 1972; Giggenbach and Le Guern, 1976; Delorme et al., 1981) they cannot be attributed unequivocally to a dep origin. They can be the result of reactions during heating of samples. Carbon can reside in microcracks, in solid inclusions like graphite, carbynes $(-\mathrm{C} \equiv \mathrm{C}-$ ) or bituminous matter (Mathez and Delaney, 1981); carbon atoms can also be inserted in silicate frameworks (Freund et al., 1982). As the temperature increases, water and carbon dioxide are reduced to hydrogen and carbon monoxide:

$$
\begin{aligned}
& \mathrm{H}_{2} \mathrm{O}+\mathrm{C} \rightleftharpoons \mathrm{CO}+\mathrm{H}_{2} \\
& \mathrm{CO}_{2}+\mathrm{C} \rightleftharpoons 2 \mathrm{CO} \text { (Boudouard reaction) } \\
& n \mathrm{CO}_{2}+\mathrm{C}_{n} \mathrm{H}_{2 n+2} \rightleftharpoons 2 n \mathrm{CO}+(n+1) \mathrm{H}_{2}
\end{aligned}
$$

Any iron, present in such material, also reduces water and carbon dioxide:

$$
\begin{aligned}
& \mathrm{H}_{2} \mathrm{O}+\mathrm{Fe} \rightleftharpoons \mathrm{FeO}+\mathrm{H}_{2} \\
& \mathrm{H}_{2} \mathrm{O}+2 \mathrm{FeO} \rightleftharpoons \mathrm{Fe}_{2} \mathrm{O}_{3}+\mathrm{H}_{2} \\
& \mathrm{CO}_{2}+\mathrm{Fe} \rightleftharpoons \mathrm{FeO}+\mathrm{CO} \\
& \mathrm{CO}_{2}+2 \mathrm{FeO} \rightleftharpoons \mathrm{Fe}_{2} \mathrm{O}_{3}+\mathrm{CO}
\end{aligned}
$$

If such reactions can proceed during analytical heating, they can also occur at depth during the rise of magmas; this explains the presence of hydrogen and carbon monoxide in fumaroles as well as in lavas. These two hypotheses mean that these two gases can have both a deep and an analytical origin.

This is further exemplified by the results obtained on CH98-DR11. The three components $\mathrm{CO}, \mathrm{H}_{2}$ and $\mathrm{CH}_{4}$ display a striking behavior. First of all, the mass spectra display good correlation between $\mathrm{CH}_{4}$ and organic masses $(26,27$, $28,41,42,43$ ) which implies that $\mathrm{CH}_{4}$ is a cracking product of heavier molecules as well. A detailed study of the carbonaceous matter contained in such samples is discussed elsewhere (Jambon and Zimmermann, 1984). One feature evidenced by the size fraction analysis is the patchy distribution of carbonaceous matter, as it is very variable from one fraction to the other without any correlation with size, as reflected by the $\mathrm{CH}_{4}$ pattern (Fig. 3). In the $500^{\circ} \mathrm{C}$ step $\mathrm{CH}_{4}$, $\mathrm{CO}$ and $\mathrm{H}_{2}$ display a positive correlation, suggesting that the two latter are the result of the decomposition of carbonaceous compounds. This feature implies that species like $\mathrm{CO}$ and $\mathrm{CH}_{4}$ (Fig. 3) obtained by thermal extraction cannot be used in thermodynamic calculations to obtain temperature or oxygen fugacity. This is not the first reported occurrence of organic compounds in MORB glasses (Hekinian et al., 1973; Mathez and Delaney, 1981) but the correlation between $\mathrm{CO}, \mathrm{CH}_{4}$ and $\mathrm{H}_{2}$ has not been reported before.

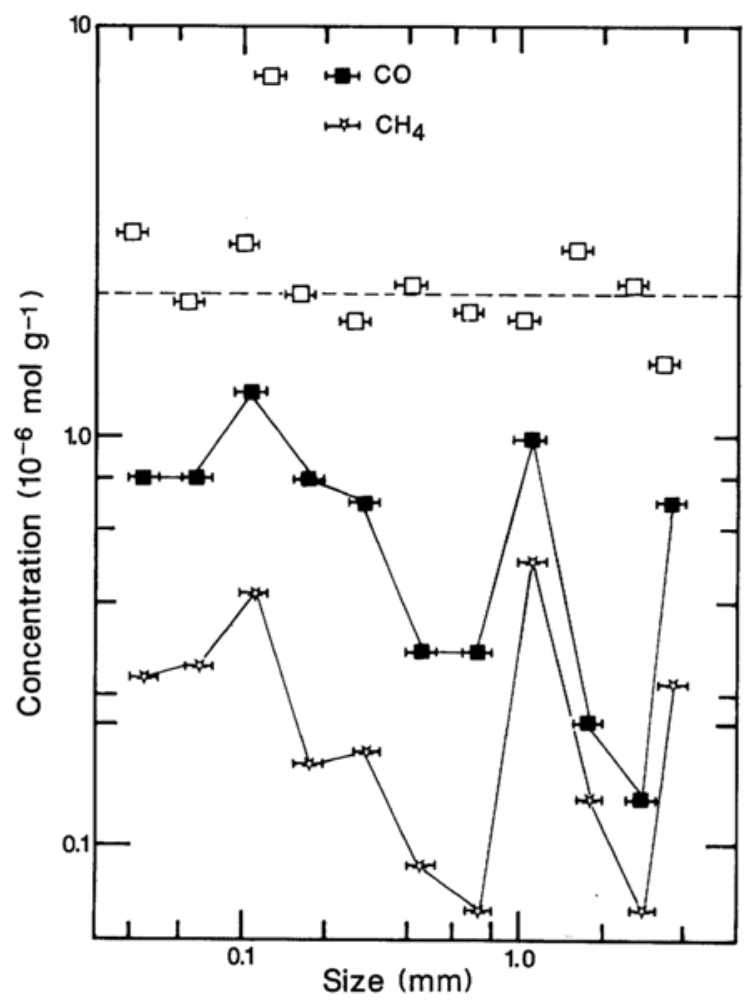

Fig. 3. Degassing pattern for several size fractions of basalt glass $\mathrm{CH} 98-\mathrm{DR} 11$. Stars $=\mathrm{CH}_{4}$, full squares $\mathrm{CO}$ both at $500^{\circ} \mathrm{C}$; Empty squares $\mathrm{CO}$ at $1200^{\circ} \mathrm{C}$. 
In the $1200^{\circ} \mathrm{C}$ temperature step, the analysed $\mathrm{CO} / \mathrm{CO}_{2}$ ratio corresponds to equilibrium with graphite at $800^{\circ} \mathrm{C}$. However for the reasons given above, this interpretation based on the thermodynamic calculation is questionable.

\section{Adsorption phenomena}

When care is taken to discard too large samples, $1200^{\circ} \mathrm{C}$ heating expels all the fluids within reasonable time, including those trapped in the lattice of solid substances. Trapping at liquid nitrogen temperature during extraction permits to minimize chemical reactions but certainly does not solve completely this problem. Room temperature crushing and stepwise heating on the same sample provide some clues to this problem too. Much larger volumes of gas are usually released by heating than by crushing. The press crushing procedure certainly minimizes adsorption on the new surfaces of the powdered material. In order to release adsorbed gases on the sample and the stainless steel, baking to $120^{\circ} \mathrm{C}$ is carried out. Adsorption being proportional to the surface area; press crushing has been preferred over ball milling. The latter yields an efficient release as smaller vesicles are destroyed, with the drawback of producing very fine material with high adsorption capability. The milling procedure is probably well suited to the quantitative recovery of inert species as exemplified in the case of $\mathrm{He}$ from the vesicles of basalt glasses (Kurz and Jenkins, 1981), while pressing is recommended for obtaining the composition of fluid inclusions (mostly $\mathrm{H}_{2} \mathrm{O}$ and $\mathrm{CO}_{2}$ ) with the inconvenience of partial recovery.

Water is the most easily and the most strongly adsorbed species; adsorption decrease in the following order $\mathrm{H}_{2} \mathrm{O}>\mathrm{CO}_{2}>\mathrm{CO}>\mathrm{CH}_{4}$ (Barker Sommer, 1973). Simultaneous trapping during extraction and reduction of water to hydrogen greatly diminishes the possibility of adsorption in the line and avoids it completely in the ionization cell. Excepting possible traces of $\mathrm{SO}_{2}$, water is the only fluid released when the cold trap at $-85^{\circ} \mathrm{C}$ is reheated.

In order to approach quantitatively the problem of adsorption upon crushing, the following

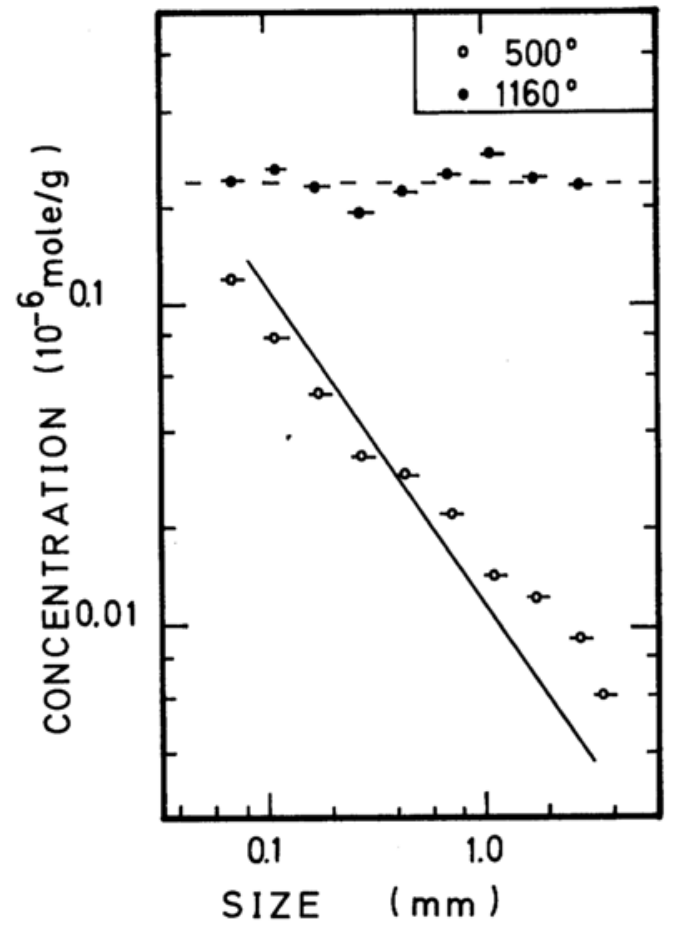

Fig. 4. Nitrogen results for basaltic glass CH87DR11. In the $500^{\circ} \mathrm{C}$ step the results are interpreted as adsorption, as the analytical points do not depart strongly from a line with -1 slope. On the other hand the high temperature step is believed to represent gas dissolved in the glass as concentration remains constant, independently of grain size.

experiment has been performed. A natural basalt glass (CH98-DR11) has been crushed in air and screened to twenty size fractions ranging from 0.040 to $4 \mathrm{~mm}$, ten of which have been analysed separately. A preliminary detailed stepwise degassing had shown that operating the first step at $500^{\circ} \mathrm{C}$ yielded the best separation between adsorbed and trapped gases. The results for $\mathrm{N}_{2}$ are presented in Fig. 4. The $500^{\circ} \mathrm{C}$ fraction can be interpreted as the result of gas adsorption on fresh surfaces: in this case one expects that the amount of gas analysed $\mathbf{M}$ is proportionated to the surface area of the sample, or the square of the grain size $r$; the amount of gas per gram $M^{\prime}$ is given by:

$$
M^{\prime}=M /\left(\alpha \rho r^{3}\right)
$$

where $\alpha$ is a geometrical factor and $\rho$ the density 
of the sample, and

$$
\log M^{\prime}=-\log r+k
$$

where $k$ is constant. The plots of $\log M^{\prime}$ vs $\log r$ give a slope of -1 (Fig. 4). On the other hand, the high temperature fraction is interpreted as representing gas dissolved in the glass since this amount is independent of grain size. From this results one can calculate a specific adsorption under the experimental conditions, of $1.8 \times 10^{-9}$ $\mathrm{mol} / \mathrm{cm}^{2}$ bar the gas fraction released between 120 and $500^{\circ} \mathrm{C}$. From this value it is possible to calculate the amount of nitrogen adsorbed on the powder upon crushing. The volume of the tube $\left(15 \mathrm{~cm}^{3}\right)$ enables to estimate the partial pressures of nitrogen. For one gram sample, reduced to a mean size of $10 \mu \mathrm{m}$, the fraction adsorbed corresponds to $0.3 \%$ of the amount released.

The other species will be comparatively more or less adsorbed depending on their relative adsorptivity, which is expected to be in the same order as their boiling point. In the case of $\mathrm{CO}_{2}$ crushing in air corresponds to $6 \times 10^{-8} \mathrm{~mol} / \mathrm{cm}^{2}$ adsorbed for a partial pressure of $4 \times 10^{-3}$ bar. If $10^{-5} \mathrm{~mol}$ of $\mathrm{CO}_{2}$ are released upon crushing, the partial pressure without adsorption would be $16 \times 10^{-3}$ bar. If adsorption is taken into account for $10 \mu \mathrm{m}$ grains, $96 \%$ of $\mathrm{CO}_{2}$ becomes adsorbed, resulting in a final $\mathrm{CO}_{2}$ pressure of $0.7 \times 10^{-3}$ bar, of a magnitude comparable to the partial pressure in air. This estimate is certainly not better than a scaling factor but it points precisely to the serious difficulty of extracting gases with high adsorptivity by crushing. A similar calculation is difficult for $\mathrm{H}_{2} \mathrm{O}$, as its partial pressure in air is variable. Its abundance in the vesicles is only a few percent of that of $\mathrm{CO}_{2}$ while its adsorptivity is probably in the same range.

\section{Conclusions}

It has been shown that the use of coupled manometric and mass spectrometric methods enables the analysis of volatile species from rocks with a very good accuracy. In particular, separation of $\mathrm{CO}_{2}$ from $\mathrm{H}_{2} \mathrm{O}$ and conversion of $\mathrm{H}_{2} \mathrm{O}$ to $\mathrm{H}_{2}$ appear to be the two most important aspects of the procedure presented here. Conjunction of crushing, stepwise heating and size fraction analysis permit to distinguish between fluid inclusions, dissolved (trapped) gases and adsorbed gases. This last aspect is not a trivial one: although $\mathrm{N}_{2}$ has no serious problem as is probably the case for $\mathrm{He}$, reactive species like $\mathrm{CO}_{2}$ and probably $\mathrm{H}_{2} \mathrm{O}$ cannot be extracted properly if rocks are crushed finely. Analysis of organic matter is very difficult. Light species may be extracted by crushing as exemplified by the quartz anlyses. Heavier non volatile species are decomposed when moderately heated, and destroyed when temperature exceeds $500^{\circ} \mathrm{C}$. Interpretation of results involving organic species as well as inorganic products derived from organic compounds $\left(\mathrm{H}_{2}, \mathrm{CO}\right)$ must be carried out with utmost care. In particular, interpretations involving, thermodynamic calculations are probably meaningless.

Acknowledgments-H. Bougault, A. Cheilletz, J. L. Cheminée, R. Hekinian, A. W. Hofmann and R. C. Maury gave the samples. Dr. T. Ohsumi reviewed the manuscript. C. W. Devey improved the English. We are grateful to D. Dautel, A. Legros for typing and illustrations. This work was partly supported by CNRS grant: ATP "Transferts". Contribution C.R.P.G. $n^{\circ} 766$.

\section{REFERENCES}

Andrawes, F. and Gibson, Jr, E. K. (1979) Release and analysis of gases from geological samples. Am. Mineral. 64, 453-463.

Barker, C. and Sommer, M. A. (1973) Mass spectrometric analysis of the volatiles released by heating or crushing rocks. Analytical methods developped for application to Lunar samples analyses. ASTM STP 539, 56-70. American Society for Testing and Materials.

Behar, F. (1978) Analyse de $\mathrm{CO}_{2}, \mathrm{H}_{2} \mathrm{O}$, hydrocarbures des inclusions fluides par chromatographie en phase gazeuse. Application aux fentes alpines et aux roches métamorphiques. Thèse 3ème cycle, Paris VII, $145 \mathrm{p}$.

Chaigneau, M. (1967) Sur les gaz occlus dans les roches de l'ére secondaire. C. R. Acad. Sci., Fr. 262D, 972-975.

Chaigneau, M. and Fuster, F. M. (1972) L'éruption du Teneguia (La Palma, Canaries) et la composition des laves et gaz fumeroliens. C. R. Acad. Sci. 
(Paris) 274D, 2948-2951.

Chamberlin, R. T. (1908) The gases in rocks. Carnegie Inst. Washington, publ. 106, 3-80.

Cheilletz, A., Dubessy, J., Kosztolanyi, Ch., MassonPerez, N., Ramboz, C. and Zimmermann, J. L. (1984) Les fluides moléculaires d'un filon de quartz hydrothermal: comparaison de techniques analytiques ponctuelles et globales, contamination des fluides occlus par des composés carbonés. Bull. Minéral. 107, 169-180.

Craig, H. (1961) Standard for reporting concentration of $\mathrm{D}$ and ${ }^{18} \mathrm{O}$ in natural waters. Science $133,1833-$ 1834.

Delorme, H., Javoy, M., Cheminée, J. L. and Pineau, F. (1981) Chemical and isotopic compositions of volcanic gases from Island Arc and continental margin (abstract). Terra Cognita 79.

Freund, F., Knobel, R., Kathrein, H., Oberheuser, G. and Schaeffer, R. G. (1982) Organic compounds in the early atmosphere formed abiotically from atomic carbon. Geol. Rundsch. 71, 1-21.

Giggenbach, W. F. and Le Guern, F. (1976) The chemistry of magmatic gases from Erta Alé, Ethiopia. Geochim. Cosmochim. Acta 40, 25-30.

Goguel, R. (1963) Die chemische Zusammensetzung der in den Mineralen einige Granites und ther pegmatites eingeschlossenen Gäses und Flüssigkeiten. Geochim. Cosmochim. Acta 27, 155181.

Gold, T. (1982) Mantle methane - fool's gold? Nature (London) 300, 312-313.

Harris, D. M. (1981) The microdetermination of $\mathrm{H}_{2} \mathrm{O}$, $\mathrm{CO}_{2}$ and $\mathrm{SO}_{2}$ in glass using a $1280^{\circ} \mathrm{C}$ microscope heating stage, cryopumping, and vapor pressure measurements from 77 to $273^{\circ} \mathrm{K}$. Geochim. Cosmochim. Acta 45, 2023-2036.

Hekinian, R., Chaigneau, M. and Cheminée, J. L. (1973) Popping rocks and lava tubes from the MidAtlantic Rift Valley at $36^{\circ} \mathrm{N}$. Nature (London) 245, 371-373.

Horowitz, H. H. and Metzger, G. (1963) A new analysis of thermogravimetric traces Anal. Chem. 35, 1464-1468.

Jambon, A. and Zimmermann, J. L. (1984) Matière carbonée dans une tholéïte de la ride médio-atlantique. 10ème RAST, Bordeaux, p. 305.

Jambon, A. and Zimmermann, J. L. (1987) Major volatiles from a North Atlantic MORB glass and calibration to He; a size fraction analysis. Chem. Geol. 62, 177-189.

Javoy, M., Pineau, F. and Iiyama, I. (1978) Experimental determination of the isotopic fractionation between gaseous $\mathrm{CO}_{2}$ and carbon dissolved in tholeiitic magma. A preliminary study. Contrib. Mineral. Petrol. 67, 35-39.
Kranz, R. L. (1970) Erste Ergebnisse organisch geochemischer Untersuchungen am Pegmatit Hagendorf-Süd. Schweiz. Mineral. Petrog. Mitt. 50, 173-182.

Kurz, M. D. and Jenkins, W. J. (1981) The distribution of helium in oceanic basalt glasses. Earth Planet. Sci. Lett. 53, 41-54.

Lafferty Mc, F. W. (1980) Interpretation of Mass Spectra. 3rd Ed. University Science Books.

Mathez, E. A. and Delaney, J. R. (1981) The nature and distribution of carbon in submarine basalts and peridotites nodules. Earth Planet. Sci. Lett. 56, 217-232.

Muenow, D. W. (1973) Occurrence of volatile nitrides from silicates in low pressure, high temperature, reducing environments. Geochim. Cosmochim. Acta 37, 2523-2528.

Piperov, N. B. and Penchev, N. P. (1973) A study of gas inclusions in minerals. Analysis of the gases from micro-inclusions in allanite. Geochim. Cosmochim. Acta 37, 2075-2097.

Price, W. F. Huntingdon, A. T. and Bailey, D. K. (1977) The effect of crushing on the release of volatile components from heated obsidian. Mineral Mag. 41, 551-553.

Reitsema, R. H. (1979) Gases of mud volcanoes in the Copper River Basin, Alaska. Geochim. Cosmochim. Acta 43, 183-187.

Roedder, E. (1972) Composition of fluid inclusions. Data of Geochemistry. U.S. Geol. Survey. Prof. Pap. 440-JJ, 164 p.

Rye, R. O. and O.'Neil, J. R. (1968) The $\mathrm{O}^{18}$ content of water in primary fluid inclusions from Providencia, North-Central Mexico. Econ. Geol. 62, 232238.

Sheppard, S. M. F. (1971) Hydrogen and oxygen isotope ratios in minerals from porphyry copper deposits. Econ. Geol. 66, 515-542.

Wahler, W. (1958) Uber die in Kristallen eingeschlossenen Flüssigkeiten und Gäses. Geochim. Cosmochim. Acta 9, 105-135.

Weisbrod, A., Poty, B. and Touret, J. (1976) Utilisation des inclusions fluides en géochimie-pétrologie: tendances actuelles. Bull. Soc. fr. Minéral. Cristallogr. 99, 140-152.

Zimmermann, J. L. (1972) L'equ et les gaz dans les principales familles de silicates. Sci. de la Terre, Fr., Mém. 22, 188 p.

Zimmermann, J. L. (1981) La libértion de l'eau, du gaz carbonique et des hydrocarbures des cordiérites. Cinétique des mécanismes. Détermination des sites. Intérêt pétrogénétique. Bull. Minéral. 104, 325-338.

Zimmermann, J. L., Cheminée, J. L. and Chaigneau, M. (1981) Etude de la phase gazeuse occluse dans 
les laves de "l'Ardoukôba", volcan éphémère d'une dorsale émergée (Afar). Bull. Volcanol. 44-3, 527-546.

Zimmermann, J. L. Vernet, M., Guyetand, G. and Dautel, D. (1985) Données sur potassium et argon (de 1976 à 1984) dans quelques échantillons géochimiques de référence. Geostand. Newsl. 9, 205-208.

Zimmermann, J. L., Cheminée, J. L. and Delorme, H. (1987) Chemical analyses and diffusion studies of gases in andestitic lavas: Arenal Volcano (Costa Rica). Chem. Geol. 61, 299-308. 